ARTIKEL PENELITIAN

\title{
Perbandingan efek pemberian ekstrak kunyit dengan ibuprofen terhadap pencegahan pembentukan adhesi pasca penyambungan tendon
}

\author{
Diki Julkarnain ${ }^{1,2}$, Dicky Mulyadi ${ }^{1,2}$, Fathurachman ${ }^{1,2}$ \\ 1. Departemen Orthopaedi dan Traumatologi, Fakultas Kedokteran, Universitas Padjadjaran; 2. RSUP \\ Dr. Hasan Sadikin, Bandung
}

Korespondensi: Diki Julkarnain; email: dikijulkarnain@gmail.com

\begin{abstract}
Abstrak
Proses penyembuhan cedera pada tendon masih sering kali terganggu dengan kejadian adhesi. Adhesi dari tendon harus dikurangi agar proses penyembuhan tendon dapat kembali ke fungsi maksimal. Salah satu cara yang dapat digunakan untuk mengurangi adhesi adalah melalui penekanan proses inflamasi. Tujuan: Untuk melihat perbandingan pemberian ekstrak kunyit dengan ibuprofen terhadap pembentukan adhesi pasca penyambungan tendon achilles kelinci. Metode: Merupakan penelitian laboratorium eksperimental dengan rancang acak sederhana dengan menggunakan 27 ekor kelinci putih jantan (ras New Zealand) yang dibagi menjadi 3 kelompok perlakuan. Tendon achilles dipotong secara tajam kemudian dijahit kembali, kemudian di-imobilisasi dengan circular cast. Kemudian masing-masing kelompok perlakuan diberikan pemberian ekstrak kunyit, ibuprofen, dan placebo pasca tindakan selama 5 hari. Hasil: Didapatkan adanya perbedaan bermakna antara kelompok perlakuan dan kelompok kontrol $(p=0.000)$, ditemukan kelompok perlakuan mengurangi adhesi lebih baik dibandingkan kelompok kontrol dan ekstrak kunyit lebih baik dibandingkan dengan ibuprofen. Simpulan: Dari penelitian ini, ekstrak kunyit lebih baik dibandingkan ibuprofen dalam pencegahan pembentukan adhesi pasca penyambungan tendon achilles kelinci.
\end{abstract}

Kata kunci: adhesi; ekstrak kunyit; ibuprofen; tendon achilles

\section{Abstract}

The process of healing injuries to tendons is still often disrupted by the occurrence of adhesions. Adhesion of the tendon must be reduced so that the healing process of the tendon can return to its maximum function. One method that can be used to reduce adhesion is through suppression of the inflammatory process. Objective: To observe comparison of the administration of turmeric extract with ibuprofen to the formation of adhesions after repair of the rabbit achilles tendon. Methods: It was an experimental laboratory study with a simple randomized design using 27 male white rabbits (New Zealand race) which were divided into 3 treatment groups. Achilles tendon is sharply cut and then repaired again, then immobilized with a circular cast. Then each treatment group was given the administration of turmeric extract, ibuprofen, and placebo for 5 days. Results: It showed a significant difference between the treatment group and the control group $(p=0.000)$, it was found the treatment group reduced adhesion better than the control group and turmeric extract was better than ibuprofen. Conclusion: This study found that turmeric extract is better than ibuprofen in preventing adhesion formation after rabbit achilles tendon attachment.

Keywords: adhesion; turmeric extract; ibuprofen; achilles tendon 


\section{PENDAHULUAN}

Cedera pada tendon termasuk cedera yang sering terjadi, baik diakibatkan oleh trauma tajam maupun trauma tumpul. ${ }^{1}$ Menurut laporan Bureau of Labor Statistics, USA, 2011, tercatat cedera muskuloskeletal merupakan 33 persen dari semua kasus inflamasi, fibrosis dan degenerasi pada jaringan muskulotendinous. ${ }^{2}$ Kasus cedera pada tendon sering ditemukan pada olahragawan, tentara maupun buruh. ${ }^{3}$ Sepanjang tahun 2004 unit gawat darurat di rumah sakit Hasan Sadikin Bandung menerima kasus cedera tendon fleksor kurang lebih 2-3 penderita setiap minggunya, sebagian besar diakibatkan oleh kecelakaan kerja. ${ }^{4}$

Dalam melakukan penatalaksanaan ruptur tendon, terdapat dikotomi antara tindakan konservatif dan operatif. Tujuan dari terapi konservatif ini adalah untuk mengembalikan dan menjaga kontak antara 2 ujung tendon yang ruptur untuk memfasilitasi penyembuhan. Terapi konservatif sangat beragam, salah satunya adalah penggunaan orthosis. Untuk tindakan operatif, terdapat beberapa teknik operasi yang dapat dikerjakan, yaitu open dan percutaneous. ${ }^{5}$

Hasil akhir penyembuhan tendon terkadang tidak memuaskan karena adanya komplikasi, di antaranya infeksi dan adhesi. $^{2}$ Salah satu komplikasi yang tersering pada penyembuhan tendon adalah adhesi. ${ }^{1,3,6}$ Adhesi membentuk jaringan fibrotik tebal antara tendon dan selubung tendon. ${ }^{2}$ Adhesi ini akan mengganggu fungsi dan mengurangi jangkauan gerakan (range of motion). ${ }^{1}$ Faktor yang mempengaruhi terjadinya adhesi antara lain adalah cedera akibat traumanya sendiri, akibat tindakan bedah, iskemia tendon, imobilisasi, adanya jarak antara dua ujung tendon, dan eksisi komponen sarung tendon. ${ }^{1-3,6}$

Penelitian terbaru menunjukkan bahwa respons inflamasi pada penyembuhan cedera tendon sebenarnya bukan merupakan faktor yang utama, karena tendon memiliki kemampuan intrinsik untuk sembuh. Tetapi mekanisme ini tertutupi oleh lebih dominannya jaringan granulasi dan fibroblas yang berasal dari jaringan sekitar tendon. ${ }^{2,3}$ Segala upaya untuk mengurangi fibroblas perifer akan membuat mekanisme penyembuhan intrinsik menjadi dominan. ${ }^{6}$

Indonesia merupakan negara yang kaya akan keanekaragaman hayati. Ada berbagai tanaman obat yang juga mengandung anti inflamasi yang alami. Salah satunya adalah kunyit (Curcuma domestica). Kunyit merupakan salah satu bahan ramuan jamu tradisional karena memiliki banyak khasiat bagi kesehatan. Beberapa khasiat dan manfaat kunyit adalah sebagai anti inflamasi, antioksidan, anti mikroba, pencegah kanker, menurunkan kadar lemak, membersihkan darah dan mengurangi rasa nyeri bagi penderita asam urat. $^{7}$

Penelitian yang dilakukan oleh Erlina Rustam, Indah Atmasari, Yanwirasti dari Fakultas Kedokteran Universitas Andalas, 
menunjukkan bahwa ekstrak etanol kunyit memiliki efek anti inflamasi (mengatasi peradangan). ${ }^{7}$ Oleh karena terjadinya adhesi dalam penyembuhan tendon dimulai oleh mekanisme ekstrinsik yang diakibatkan proses inflamasi yang berlebihan, maka dalam upaya penghambatan mekanisme ekstrinsik melalui penekanan proses inflamasi peneliti mencoba membandingkan penggunaan ekstrak kunyit dan ibuprofen sebagai suatu upaya untuk mengurangi adhesi dalam proses penyembuhan cedera tendon.

\section{METODE}

Penelitian ini merupakan penelitian laboratorium eksperimental terhadap hewan percobaan (kelinci) dengan desain penelitian rancang acak sederhana (simple random sampling).

Teknik Pengumpulan dan Pengolahan Data adalah sebagai berikut: (1) Perlakuan kelinci baru selama 1 minggu untuk adaptasi kelinci di laboratorium (conditioning); (2) Kelinci yang telah memenuhi kriteria penelitian dilakukan penomoran acak genap dan ganjil, kelompok yang bernomor genap menjadi kelompok I diberikan ibuprofen per oral. Kelompok yang bernomor ganjil menjadi kelompok II diberikan ekstrak kunyit per oral. Hewan dipelihara di laboratorium selama tiga minggu dengan diet bebas; (3) Kelinci dibius dengan memberikan ketamine $(150 \mathrm{mg} / \mathrm{kgBB})$ intramuskuler, lalu rambut di sekitar tempat pemotongan tendon achilles dicukur dan dilakukan tindakan aseptik dan antisepsis dengan menggunakan povidone iodine 10\%; (4) Pada kelinci tersebut dilakukan insisi kulit longitudinal sepanjang $2 \mathrm{~cm}$, kutis dan subkutis, identifikasi tendon achilles dan pemutusan tendon achilles (transversal) secara tajam dan tendon dijahit dengan menggunakan metode modified Kessler dengan menggunakan prolene 3.0 dan kulit dijahit dengan dafilon 3.0 serta dilakukan perawatan luka dan pemberian antibiotik ceftriaxone (50 mg/kgBB) intramuskuler selama 3 hari. Dilakukan pemberian ibuprofen per oral pada kelompok I hewan perlakuan dengan dosis $75 \mathrm{mg} / \mathrm{kgBB}$, sedangkan pada kelompok II hewan perlakuan diberikan ekstrak kunyit dengan dosis $80 \mathrm{mg} / \mathrm{kgBB}$, kemudian dilakukan imobilisasi dalam posisi plantar fleksi penuh dengan menggunakan circular casting. Hewan coba dipelihara untuk kemudian dilakukan pengambilan sampel; (5) Setelah tiga minggu dilakukan nekropsi kelinci dengan menggunakan phenobarbital intravena dengan dosis 100 $\mathrm{mg} / \mathrm{kgBB}$, diambil sejumlah jaringan di sekitar luka sejajar dengan ujung pertemuan kedua stump secara end-block dari bawah kulit, tendon dan jaringan sekitar tulang, kemudian di-fiksasi dengan menggunakan formalin 10\%; (6) Sediaan dibawa ke laboratorium Patologi Anatomi Rumah Sakit Hasan Sadikin untuk dibuat sediaan histopatologi. Setelah itu, dilakukan pemeriksaan histopatologis dengan pulasan hematoxyline-eosine dan diperiksa di bawah mikroskop cahaya oleh ahli Patologi Anatomi (blinded) untuk menilai derajat adhesi berdasarkan kriteria 
Tang dkk. ${ }^{8} \quad$ Kemudian dilakukan perhitungan statistik dengan menggunakan Mann-Whitney test. ${ }^{9}$; (7) Hasil pengumpulan data dilakukan uji statistik menggunakan Mann-Whitney test (program SPSS versi 24.0 for Windows) dengan nilai signifikansi $p<0,05 .^{9}$

\section{HASIL DAN PEMBAHASAN}

Tujuan penelitian ini adalah untuk melihat perbedaan pengaruh pemberian ekstrak kunyit dan ibuprofen per oral terhadap pencegahan pembentukan adhesi pasca repair tendon achilles kelinci. Penelitian ini merupakan penelitian laboratorium eksperimental terhadap hewan percobaan dengan desain penelitian rancang acak sederhana (simple random sampling). Obyek penelitian adalah kelinci putih ras New Zealand dewasa muda jantan dengan berat badan antara 1000-1500 gram dan berumur 7 bulan. Jumlah sampel diperoleh sebesar 27 kelinci yang dibagi menjadi 3 kelompok yaitu kelompok kontrol, kelompok curcuma dan kelompok ibuprofen masing-masing sebesar 9 kelinci.

Pada kelompok perlakuan yang diberikan ibuprofen per oral dan diberikan ekstrak kunyit per oral dipelihara di laboratorium selama tiga minggu dengan diet bebas. Kemudian kelinci dibius dengan memberikan ketamine (150 mg/kgBB) intramuskuler, lalu rambut di sekitar tempat pemotongan tendon achilles dicukur dan dilakukan tindakan aseptik dan antiseptik dengan menggunakan povidone iodine $10 \%$. Pada kelinci tersebut dilakukan insisi kulit longitudinal sepanjang $2 \mathrm{~cm}$, kutis dan subkutis, identifikasi tendon achilles dan pemutusan tendon achilles (transversal) secara tajam dan tendon dijahit dengan menggunakan metode modified Kessler dengan menggunakan prolene 3.0 dan kulit dijahit dengan dafilon 3.0 serta dilakukan perawatan luka dan pemberian antibiotik ceftriaxone (50 $\mathrm{mg} / \mathrm{kgBB}$ ) intramuskuler selama 3 hari. Dilakukan pemberian ibuprofen peroral pada kelompok ibuprofen hewan perlakuan dengan dosis $75 \mathrm{mg} / \mathrm{kgBB}$, sedangkan pada kelompok curcuma hewan perlakuan diberikan ekstrak kunyit dengan dosis $80 \mathrm{mg} / \mathrm{kgBB}$, kemudian dilakukan imobilisasi dalam posisi plantar fleksi penuh dengan menggunakan circular casting. Hewan coba dipelihara untuk kemudian dilakukan pengambilan sampel.

Setelah dilakukan perlakuan dan pengumpulan data, sediaan akhir jaringan yang didapatkan kemudian diperiksa di laboratorium Patologi Anatomi RSUP Dr. Hasan Sadikin dengan pulasan hematoxyline-eosine dan diperiksa di bawah mikroskop cahaya oleh ahli Patologi Anatomi (blinded) untuk menilai derajat adhesi.

Tabel 1. Deskripsi derajat adhesi setiap kelompok

\begin{tabular}{lccc}
\hline Kelompok & Min. & Maks. & Median \\
\hline Kontrol & 3 & 4 & 3 \\
Curcuma & 2 & 3 & 2 \\
Ibuprofen & 3 & 4 & 3 \\
\hline
\end{tabular}

Berdasarkan Tabel 1, diperoleh bahwa penilaian derajat adhesi berdasarkan histopatologis tendon achilles kelinci. Untuk kelompok kontrol mempunyai nilai 
minimum 3, maksimum 4, dan median sebesar 3. Kelompok perlakuan curcuma yang mempunyai nilai minimum sebesar 2 , maksimum 3 dan median sebesar 2 . Kelompok perlakuan ibuprofen nilai minimum 3, maksimum 4 dan median sebesar 3 .

Tabel 2. Uji normalitas data derajat adhesi

\begin{tabular}{lcc}
\hline Kelompok & $p$ & Keterangan \\
\hline Kontrol & 0,000 & Tidak normal \\
Curcuma & 0,000 & Tidak normal \\
Ibuprofen & 0,000 & Tidak normal \\
\hline
\end{tabular}

Tabel 2 pada uji normalitas terlihat bahwa nilai $\mathrm{p}$ pada derajat adhesi kelompok kontrol, kelompok curcuma dan kelompok ibuprofen sebesar 0,000 , sehingga data derajat adhesi ketiga kelompok tersebut terdistribusi tidak normal, maka dilakukan dengan analisis non parametrik yaitu uji Kruskall-Wallis dan uji Mann-Whitney.

Penelitian ini merupakan penelitian eksperimental untuk melihat perbedaan pengaruh pemberian ekstrak kunyit per oral dengan ibuprofen per oral terhadap pencegahan pembentukan adhesi peritendinous pasca penyambungan tendon achilles kelinci. Penelitian ini menggunakan kelinci sebagai binatang percobaan, dengan pertimbangan kelinci merupakan hewan mamalia yang mempunyai tendon achilles yang cukup besar dan bentuknya menyerupai tendon fleksor tangan manusia. ${ }^{10}$

$\begin{array}{lrr}\text { Pentingnya } & \text { pencegahan } & \text { adhesi } \\ \text { peritendineous } & \text { adalah } & \text { untuk }\end{array}$
mengembalikan fungsi gliding tendon. ${ }^{11}$ Timbulnya adhesi antara tendon dengan jaringan di sekitarnya mengakibatkan gangguan fungsi pergerakan jari-jari yang akan memberikan efek tidak optimalnya fungsi tangan. ${ }^{12}$

Mekanisme intrinsik pada proses penyembuhan tendon menyokong bahwa proses inflamasi dan pembentukan adhesi tidak diperlukan. Jika mekanisme ekstrinsik dominan, maka akan terjadi adhesi antara tendon dan jaringan sekitarnya. Hal ini menunjukkan bahwa usaha untuk menghilangkan fibroblas perifer pada daerah penyembuhan sangat berpengaruh, karena akan membuat mekanisme intrinsik menjadi dominan. ${ }^{13}$

Berbagai faktor dapat menyebabkan terjadinya adhesi, cedera akibat trauma yang merusak struktur tendon dan sarung tendon, derajat iskemia tendon, imobilisasi lama, dan kerusakan komponen sarung tendon saat operasi sangat berpengaruh terhadap timbulnya adhesi. Zhao, dkk. mendapatkan bahwa teknik penjahitan yang menimbulkan gesekan lebih banyak akan menimbulkan derajat adhesi yang lebih berat. ${ }^{14}$

Beberapa peneliti terdahulu telah berusaha untuk menemukan metode dan teknik dalam usaha mencegah timbulnya adhesi. Teknik yang dikembangkan baik secara mekanik, secara farmakologi maupun biologi molekuler. ${ }^{13}$

Penelitian ini menggunakan ekstrak kunyit dan ibuprofen sebagai bahan dalam pencegahan terbentuknya adhesi peritendinous pasca penyambungan tendon achilles kelinci. Dari ketiga kelompok hewan coba, setelah tiga minggu 
perlakuan, jaringan yang diteliti diambil secara end-block dan diperiksa secara histopatologis oleh ahli Patologi Anatomi (blinded) untuk menilai derajat adhesi berdasarkan kriteria Tang dkk. yang dilihat pada Tabel 3.

Tabel 3. Derajat adhesi menurut Kriteria Tang ${ }^{8}$

\begin{tabular}{ll}
\hline Nilai & Tampilan adhesi \\
\hline Kuantitas & \\
0 & Tidak tampak adhesi \\
1 & Terdapat sedikit filamen \\
2 & Terdapat banyak filamen \\
3 & Filamen tidak terhitung \\
Kualitas & \\
0 & Tidak tampak adhesi \\
1 & Filamen yang tersusun rapi \\
2 & Filamen tidak teratur \& pendek \\
3 & Padat \\
Total & \\
derajat & \\
adhesi & \\
0 & Tidak ada adhesi \\
$1-2$ & Adhesi ringan \\
$3-4$ & Adhesi sedang \\
$5-6$ & Adhesi berat \\
\hline
\end{tabular}

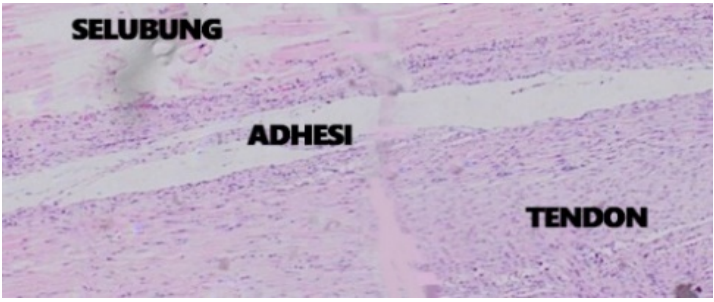

Gambar 1. Kelompok perlakuan (curcuma)

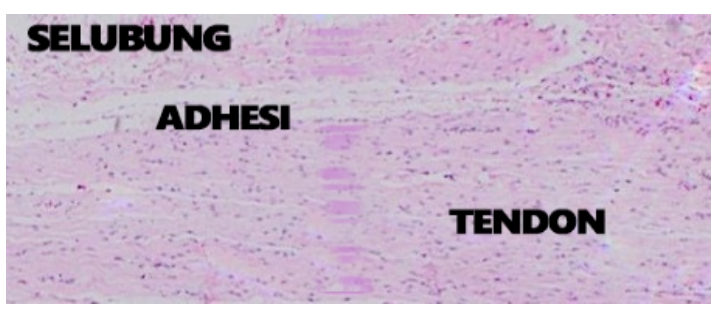

Gambar 2. Kelompok perlakuan (ibuprofen)

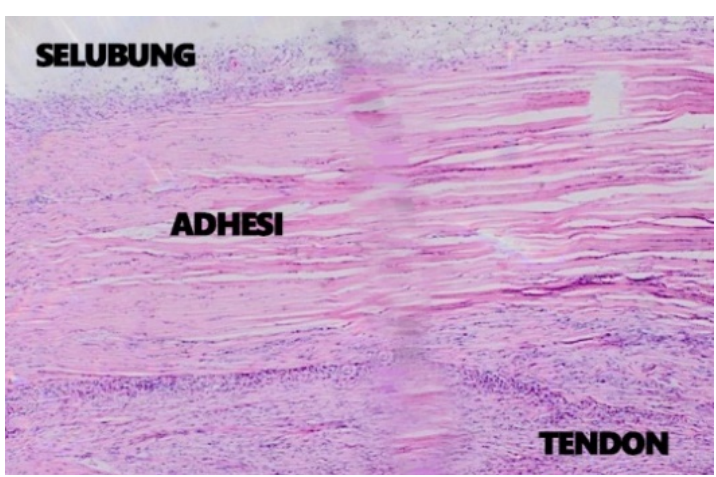

Gambar 3. Kelompok kontrol

Berdasarkan klasifikasi derajat adhesi menurut Tang dkk. menunjukkan adanya perbedaan yang bermakna antara kelompok perlakuan. Uji statistik data non parametrik menggunakan Mann-Whitney menunjukkan adanya perbedaan yang bermakna antara ketiga kelompok hewan coba. Hal ini menunjukkan bahwa ekstrak kunyit lebih baik dibandingkan dengan ibuprofen dalam mencegah terjadinya adhesi peritendineous.

Pada penelitian ini, dilakukan beberapa metode untuk meminimalkan bias dengan menggunakan hewan coba yang homogen, teknik perawatan dan perlakuan yang sama. Untuk memastikan ujung tendon yang dipotong tetap dekat, tungkai diposisikan pada posisi fleksi plantar penuh dan diimmobilisasi dengan gips sirkuler.

Hasil penelitian ini menunjukkan bahwa ekstrak kunyit mempunyai pengaruh terhadap derajat pembentukan adhesi secara bermakna pada kelinci, sehingga ekstrak kunyit kemungkinan memiliki kemampuan untuk proses penyembuhan cedera tendon achilles kelinci. Cedera tendon merupakan cedera yang sering terjadi dan masih merupakan masalah dalam pengelolaannya, salah satu 
komplikasi yang timbul adalah adhesi. Fase penyembuhan tendon dimulai dari fase inflamasi, dimana pada fase inflamasi dimulai dengan peran dari sel mast, yang melepas histamin, tumor necroting factor$\alpha$ (TNF- $\alpha$ ) serta sitokin sebagai faktor inisiasi proses inflamasi. Fibroblas adalah sel yang bertanggung jawab terhadap proses penyembuhan tendon. Sekaligus pada tingkat selular, fibroblas bertanggung jawab terhadap terjadinya adhesi antara tendon dan selubung fleksor atau jaringan sekitarnya.

Ekstrak kunyit merupakan zat alami yang mempunyai efek anti inflamasi. Ekstrak kunyit mampu mencegah aktivasi sel mast dalam mengatur respon inflamasi.
Menurut Ok-seon dkk. ekstrak kunyit mampu mencegah aktivasi sel mast karena sel mast berperan dalam mengatur respon inflamasi, pada hewan coba yang mengalami inflamasi mengalami peningkatan jumlah sel mast. Oleh sebab itu, dapat dikatakan bahwa stabilisasi sel mast mungkin merupakan mekanisme kunci untuk melindungi saluran pencernaan dari cedera. ${ }^{13}$

\section{SIMPULAN}

Pemberian ekstrak kunyit per oral lebih baik dibandingkan dengan ibuprofen per oral dalam mencegah pembentukan adhesi pasca penyambungan tendon achilles kelinci.

\section{DAFTAR PUSTAKA}

1. Seiler III JG. Flexor Tendon Injury. In: Wolfe S, Pederson W, Kozin SH, Cohen M. Green's Operative Hand Surgery. $7^{\text {th }}$ Ed. Philadelphia: Churchill Livingstone; 2016. p.183-226.

2. Gao HG, Fisher PW, Lambi AG, Wade CK, Barr-Gilliespie AE, Popoff SN, et al. Increased serum and musculotendinous fibrogenic proteins following persistent low-grade inflammation in a rat model of long-term upper extremity overuse. PLoS One. 2013; 8(8):e71875. doi: 10.1371/journal.pone.0071875. [PubMed] [PMC free article].

3. Courneya JP, Luzina IG, Zeller CB, Rasmussen JF, Bocharov A, Schon LC, et al. Interleukins 4 and 13 modulate gene expression and promote proliferation of primary human tenocytes. Fibrogenesis Tissue Repair. 2010; 3:9. doi: 10.1186/1755-1536-3-9. [PubMed] [PMC free article].

4. Hermana D. Cedera flexor tendon. In: Data status unit gawat darurat. Bandung: RS Hasan Sadikin; 2004.

5. Gulati V, Jaggard M, Al-Nammari SS, Uzoigwe C, Gulati P, Ismail N, et al. Management of achilles tendon injury: A current concepts systematic review. World J Orthop. 2015; 6(4):380-6. doi: 10.5312/wio.v6.i4.380. [PMC free article].

6. Güngörmüş $C$, Çetinkaya MA, Demirutku A. A new model for partial immobilization of rat hind limb after Achilles tendon excision/re-interposition. Turk J Vet Anim Sci. 2013; 37(5):546-52. doi: 10.3906/vet-1206-8.

7. Rustam E, Atmasari I, Yanwirasti. Efek Antiinflamasi Ekstrak Ethanol Kunyit (Curcuma domestica Val) Pada Tikus Putih Jantan Galur Wistar. Jurnal Sains dan Teknologi Farmasi. 2007; 12(2):112-5. 
8. Tang JB, Shi D, Zhang QG. Biomechanical and histologic evaluation of tendon sheath management. J Hand Surg Am. 1996; 21(5):900-8. doi: 10.1016/S0363-5023(96)80212-7. [PubMed].

9. Sudigdo S. Dasar-dasar metodologi Penelitian Klinis. Edisi ke-4. Jakarta: Sagung Seto; 2011.

10. Trumble TE. Experimental Studies of the Structure and Function of Flexor Tendons. In: Light TR, American Society for Surgery of the Hand (editor). Hand Surgery Update 2. American Academy of Orthopaedic Surgeons; 1999. p.129-40.

11. Harrison RK, Jones ME, Clayton E, Grobbelaar AO, Sanders R. Mapping of vascular endothelium in the human flexor digitorum profundus tendon. J Hand Surg Am. 2003; 28(5):806-13. doi: 10.1016/s0363-5023(03)00301-0. [PubMed].

12. Ozgenel GY, Samli B, Ozcan M. Effects of human amniotic fluid on peritendinous adhesion formation and tendon healing after flexor tendon surgery in rabbits. J Hand Surg Am. 2001; 26(2):332-9. doi: 10.1053/jhsu.2001.22524. [PubMed].

13. Gelberman R, Goldberg V, Kai-Nan A, Banes A. Tendon. In: Woo SL, Buckwalter J, editors. Injury and Repair of the Musculoskeletal Soft Tissues. Park Ridge, IL: American Academy of Orthopedic Surgeons; 1988. p.5-40.

14. Zhao C, Amadio PC, Momose T, Couvreur P, Zobitz ME, An KN. The effect of suture technique on adhesion formation after flexor tendon repair for partial laceration in canine model. J Trauma. 2001; 51(5):917-21. doi: 10.1097/00005373-200111000-00015. [PubMed]. 